\title{
Predicting Fractured Carbonate Reservoirs at the Early Stage of Exploration of Oil and Gas Deposits
}

\author{
Gatsayeva S.S. - A. \\ Department of Applied Geophysics and Geoinformatics \\ Grozny State Oil Technical University \\ Grozny, Russia \\ e-mailsveta_gacaeva@mail.ru \\ Elzhayev A.S. \\ Department of Applied Geophysics and Geoinformatics \\ Grozny State Oil Technical University \\ Complex R\&D Institute of the Russian Academy of \\ Sciences \\ Grozny, Russia \\ e-mail aclambek.elzhaev@mail.ru
}

Gatsayeva L.S.

Complex R\&D Institute of the Russian Academy of Sciences

Grozny, Russia

\author{
Aleksandrov B.L. \\ Department of Physics \\ Kuban State Agricultural University \\ Krasnodar, Russia \\ e-mail trudkubgau@kubagro.ru
}

\author{
Khasanov M.A. \\ Department of Applied Geophysics and Geoinformatics \\ Grozny State Oil Technical University \\ Complex R\&D Institute of the Russian Academy of \\ Sciences \\ Grozny, Russia \\ e-mail aclambek.elzhaev@mail.ru
}

\author{
Ezirbayev T.B. \\ Geophysics Laboratory \\ Complex R\&D Institute of the Russian Academy of \\ Sciences \\ Grozny State Oil Technical University \\ Grozny, Russia \\ e-mail timersno@mail.ru
}

\author{
Abubakarova E.A. \\ Geophysics Laboratory \\ Complex R\&D Institute of the Russian Academy of Sciences \\ Grozny, Russia \\ e-mail eliza_ggni@mail.ru
}

\begin{abstract}
The paper considers a possibility of using complex information on morphological parameters of structures, unconnected porosity and reservoir pressure gradient for previously explored deposits for developing a multidimensional equation to estimate the secondary porosity on an example of reservoirs with secondary (fracturing) porosity of Upper Cretaceous deposits in the Terek-Sunzha oil and gas bearing region of Pre-Caucasus. This equation allows predicting the secondary porosity value in new anticlinal structures revealed with seismic survey at later stages of exploration in the respective oil and gas bearing region and using it as a quantitative criterion to predict existence of an entrainment trap.
\end{abstract}

Keywords - fractured reservoir, oil and gas deposit, porosity, prediction, carbonate sediments, Tersek-Sunzha oil and gas bearing region

\section{INTRODUCTION}

More than $60 \%$ of all the oil produced globally is confined to carbonate reservoirs, predominantly those of fractured type.
The global initial recoverable reserves of oil linked to this group of reservoirs are estimated at over 6 billion tons of commercial oil, the global proven reserves are estimated at approximately 63 trillion $\mathrm{m}^{3}$ [14].

In the territory of the Russian Federation, oil and gas deposits in fractured reservoirs are found in various tectonic conditions and in sediment sheaths of various age. Fractured reservoirs have the paramount importance in determining the prospects of oil and gas presence, for example in the oil and gas bearing region of East Siberia. Thus, importance and topicality of any developments related to the issues of fractured reservoirs are obvious, as many related issues are understudied. First of all, it is true of exploration attributes of reservoirs in low porosity rock, which are impossible to identify without considering the formation factors of fractured reservoir rocks. The problem of fractured reservoirs gets special topicality and complexity when considering the prospects of the carbonate reservoirs located in extreme conditions at deep depths. 


\section{ANALYSIS OF EXPLORATION DEGREE OF THE FRACTURING FORMATION MECHANISM IN ROCKS AND METHODS FOR ITS IDENTIFICATION}

One of major factors in oil and gas reservoir formation in carbonate rocks is development of fractures. As for genesis and mechanism of rock fracturing, there are several points of view, often mutually exclusive [3, 4 and others].

Studies of fracturing develop along several lines of research. Continuum mechanics and solid state physics develop a general understanding of the laws governing formation and development of hard rock fracturing. Rock mechanics pays major attention to the problems of plasticity and strength of rocks, that is, to determination of conditions of attaining limiting strain states. Currently, there is a quite definitive and experimentally confirmed understanding of the atomic mechanism of plastic deformation and solid body breakdown related to developments in the dislocation theory.

The most complete summary of this line of research may be found in proceedings of two international conferences that were held in the US in 1959-1962. There, the main attention was paid to appearance of cracks in various solid bodies, at that, all the main types of solid body destruction (brittle, viscous, fatiguerelated) were considered in the context of a unified paradigm of dislocation mechanism during the deformation. Kinetics of the fracture process linked to dislocation development is schematically represented as a consecutive transition from glide and merging of dislocations, leading to local concentration of stress and formation of proto-fractures, their development and joining, up to formation of the main destructive fracture.

Formation of oil and gas deposits in carbonate rock massifs is usually possible on condition of presence of fracture porosity therein. Due to this, it is very important to reveal presence of fractured reservoirs in carbonate section throughout the stages of oil and gas deposit exploration, including:

1) preliminary prediction of possible presence of fractured reservoirs from the results of field seismic [9,10,14], geomorphological [3,5] and aerospace [1, 2, 4, 7] surveys. Thanks to aerospace methods' inherent ability of obtaining information on the same natural features, retrospective analysis becomes easy. It allows studying the dynamics of the geological processes $[3,4,14]$;

2) identification of reservoirs while drilling from the results of geological and engineering survey (GES) data ;

3) complex study of oil-bearing of the carbonate sediments and detailed identification of fracture reservoirs ranges in carbonate massifs with well surveys after completion $[3,9,10]$.

As well drilling is associated with large financial and material costs, it is very important to produce the preliminary prediction for the presence of reservoir in the carbonate massif at the first stage, that is, from the results of seismic surveying of anticlinal structures. According to modern theoretical understanding of fracture reservoir formation mechanism [5], the amount of fracture porosity in carbonate massif is largely influenced by the strength of rocks, fault morphology and reservoir pressure. In $[6,11]$, influence of various morphological parameters has been revealed, including the angle at the knee of a fold leading to strain loads arising that form fracturing. According to modern understanding $[11,12]$, reservoir formation proceeds simultaneously with formation of the structural layout. Tectonic movements cause redistribution of stress field, leading to intensive formation of a system of fractures. It is related to tectogenesis phases and has cyclic nature. At that, formation of a fractured reservoir is largely influenced by the presence of tectonic faults [15.]

One of informative methods to identify the fault zones is a method of paleotectonic studies by means of analyzing thickness distribution [14]. The fractured discontinuous faults that were active in contemporary history appear on the daylight surface especially vivid. This notion is supported by a large number of foreign [3, 13] and Russian [8 and others] research works. The most impressive results were obtained by Blanchet and Hodgson [13]. The researchers reported, that the systematic layout of dislocations found in more ancient rock was almost completely repeated in all the later sedimentary systems.

\section{PREDICTION OF FRACTURED RESERVOIRS}

The problem of formation of reservoirs with fracture porosity on the example of Upper Cretaceous sediments of Terek-Sunzha region was considered in a number of previous works [8 and others].

For example, the authors of [10] proposed combined use of information on morphological structural features and proved an empiric multidimensional equation (1), that allows calculating the value of secondary (fractured) porosity (Ksfp, \%) from such parameters as depth of the fold hinge $(\mathrm{H}, \mathrm{km})$, maximum bending of strata $(\mathrm{i}, \mathrm{m})$, area $\left(\mathrm{S}, \mathrm{km}^{2}\right)$, intensity of fault formation $\left(\mathrm{J}=\mathrm{i} / \mathrm{S}, \mathrm{m} / \mathrm{km}^{2}\right)$, predicted value of unconnected porosity $\left(\mathrm{K}_{\mathrm{up}}, \%\right)$ and reservoir pressure gradient $(\mathrm{P}, \mathrm{mPa} / \mathrm{m})$, and then, considering $0.2 \%$ as a critical value, draw conclusions on practicality of drilling the first well in the crest of the structure, as well as on the order of well drilling.

$$
\begin{gathered}
\mathrm{K}_{\text {sfp }}=3 \cdot 10^{-4} \mathrm{i}+0,895 \cdot \operatorname{gradP}+2.5 \cdot 10^{-2} \mathrm{~J}- \\
-2.58 \cdot 10^{-2} \mathrm{~K}_{\text {up }}-6,67 \cdot 10^{-2} \mathrm{H}-0,945
\end{gathered}
$$

Under some conditions, the information is incomplete, and it become problematic to use the equation (1) to calculate the value of $K_{\text {пвт. }}$. Due to this, to increase the efficiency of exploration of territories prospective for oil and gas that are related to the zones of maximum dislocation tectonics, and as a result, those of maximum fracturing, the authors conducted the following research.

From the material of seismic exploration survey conducted in the Terek-Sunzha oil and gas bearing region, outlines of the structures were identified for the reflective Upper Cretaceous sediments of interest (Fig.1). 


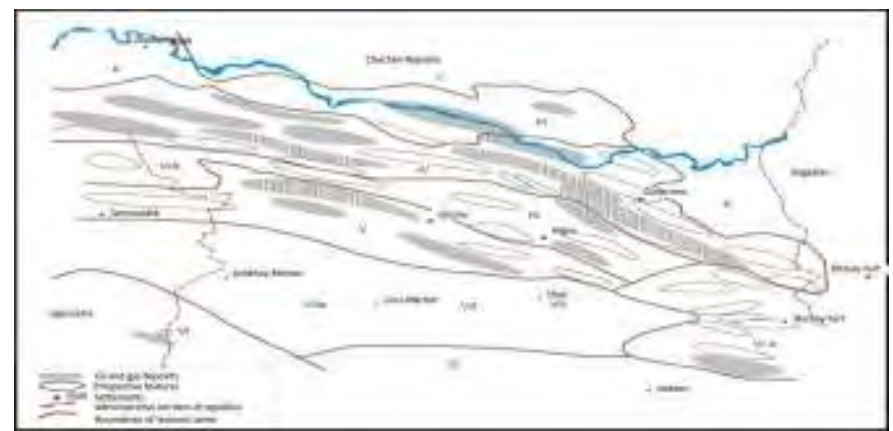

Fig. 1. A diagram of location of oil and gas deposits within the Terek-Sunzha zone, with elements of tectonic zoning of the Terek-Caspian depression

I - Monocline of the northern margin, II - Pre-Terek depression, III - Near-Terek anticlinal zone,

IV - Terek anticlinal zone,V-Sunzha anticlinal zone, VI - Chernogorsk monocline, VII - Chechen basin, VIII- Alkhanchurt syncline, IX Petropavlovsk sincline, $\mathrm{X}$ - Sulak basin.

Then, spacial positions of disruptive faults were established throughout the studied territory along this reflective horizon (Fig. 2).

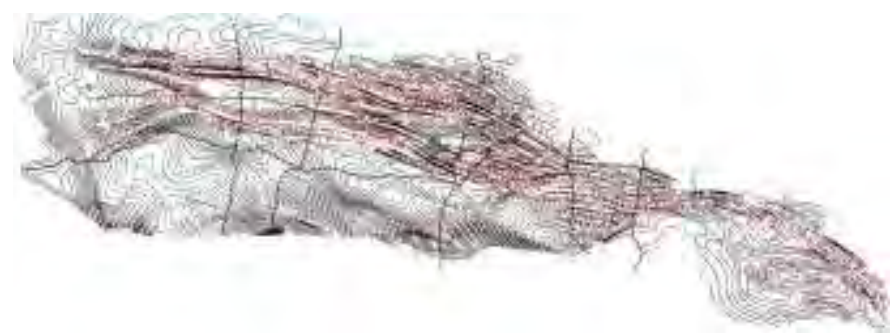

Fig. 2. Structural map along the overburden of Upper Cretaceous sediments with disruptive faults in the territory of Terek-Caspian depression

The studied territory was divided into equal squares with $5 \mathrm{~km}$ sides and for each square the number of disruptive faults was determined. After that, these values were put into centers of respective squares and a map was plotted to reflect the height contours of along the same values of the disruptive faults (Fig $3)$.

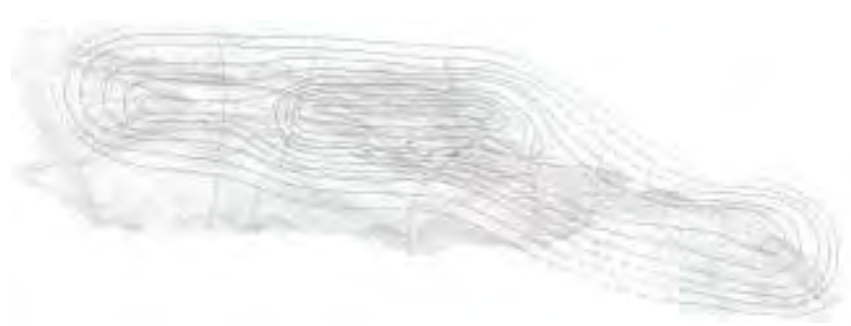

Fig. 3. A map of height contours of disruptive faults for Upper Cretaceous sediments in the territory of Terek-Caspian depression Capacity and filtration properties of Upper Cretaceous rocks with breakdown per deposit (According to data from North Caucasus branch of NIPIneft)

As it is evident from analysis of this map, a zone of maximum values of the disruptive faults is revealed that includes the largest deposits in the Upper Cretaceous sediments (Malgobek-Voznesenskoye, Bragunskoye, Eldarovskoye on Terek mountain range; Starogroznenskoye and Zamankulskoye on Sunzha mountain range); reservoirs of these deposits are characterized with the highest fractured (secondary) porosity from both hydrodynamics and field geophysical data (Tables 1, 2, 3).

Thus, this method may be employed to predict the fractured reservoir development zones in sedimentary sheath ina new unstudied territory. Drilling of the first wells is practical in the crest of the structures, which pertain to the zone of maximum disruptive faults.

Thus, the results of the conducted research have not only theoretical, but also important practical value, mainly for targeting of exploratory works.

TABLE I. CAPACITY AND FILTRATION PROPERTIES OF UPPER CRETACEOUS ROCKS WITH BREAKDOWN FOR DEPOSITS (ACCORDING TO DATA FROM NORTH CAUCASUS BRANCH OF NIPINEFT)

\begin{tabular}{|c|c|c|c|c|}
\hline \multirow[b]{2}{*}{$\begin{array}{l}\stackrel{0}{\circ} \\
\stackrel{0}{0} \\
\stackrel{0}{0}\end{array}$} & \multicolumn{3}{|c|}{ Laboratory Core Studies } & \multirow[b]{2}{*}{ 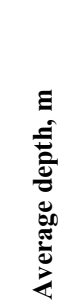 } \\
\hline & 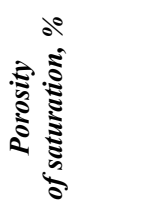 & 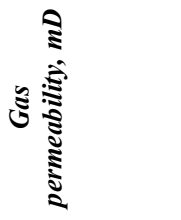 & 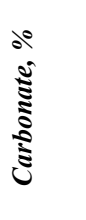 & \\
\hline \multirow{2}{*}{$\begin{array}{c}\text { Malgobek- } \\
\text { Voznesenskoye }\end{array}$} & $0.1-16.4$ & $0.00006-1$ & \multirow[b]{2}{*}{91} & \multirow[t]{2}{*}{2850} \\
\hline & 4.4 & 0.05 & & \\
\hline \multirow{2}{*}{$\begin{array}{c}\text { Khayan- } \\
\text { Kortovskoye }\end{array}$} & $0.3-6.4$ & $0.0005-0.3$ & \multirow[t]{2}{*}{76} & \multirow[t]{2}{*}{3500} \\
\hline & 2.16 & 0.07 & & \\
\hline \multirow{2}{*}{$\begin{array}{c}\text { Eldarovsky } \\
.\end{array}$} & $0.15-8.3$ & $0.00001-0.9$ & \multirow[t]{2}{*}{87} & \multirow[t]{2}{*}{4050} \\
\hline & 2.3 & 0.07 & & \\
\hline \multirow[t]{2}{*}{ Bragunskoye } & $1.6-9.4$ & $0.0002-0.012$ & \multirow[t]{2}{*}{84} & \multirow[t]{2}{*}{4650} \\
\hline & 4.0 & 0.003 & & \\
\hline \multirow{2}{*}{$\begin{array}{l}\text { Goryacheistoch } \\
\text { nenskoye }\end{array}$} & $0.2-4.5$ & $0.00005-0.07$ & \multirow[t]{2}{*}{92} & \multirow[t]{2}{*}{4300} \\
\hline & 1.7 & 0.01 & & \\
\hline \multirow[t]{2}{*}{ Gudermes } & $0.3-4.9$ & $0.00002-0.13$ & \multirow[t]{2}{*}{92} & \multirow[t]{2}{*}{5000} \\
\hline & 1.7 & 0.016 & & \\
\hline \multirow{2}{*}{$\begin{array}{c}\text { Mineralnenskoy } \\
\text { e }\end{array}$} & $0.7-6.5$ & $0.00005-0.056$ & \multirow[t]{2}{*}{89} & \multirow[t]{2}{*}{5100} \\
\hline & 2.4 & 0.01 & & \\
\hline \multirow{2}{*}{$\begin{array}{c}\text { Zamankulskoye } \\
\text {. }\end{array}$} & $1.3-19.4$ & $0.010-0.08$ & \multirow[t]{2}{*}{94} & \multirow[t]{2}{*}{2200} \\
\hline & 3.7 & 0.05 & & \\
\hline \multirow{2}{*}{$\begin{array}{c}\text { Karabulak- } \\
\text { Achalukskoye }\end{array}$} & $1.0-25.0$ & $0.0005-0.7$ & \multirow[t]{2}{*}{97} & \multirow[t]{2}{*}{2200} \\
\hline & 5.6 & 0.03 & & \\
\hline \multirow{3}{*}{$\begin{array}{c}\text { Starogroznensko } \\
\text { ye }\end{array}$} & $0.7-14.1$ & $0.00001-0.01$ & \multirow[t]{3}{*}{95} & \multirow[t]{3}{*}{4600} \\
\hline & 3.4 & 0.002 & & \\
\hline & 0.7 & 0.004 & & \\
\hline
\end{tabular}


TABLE II. HYDRODYNAMIC STUDIES INTO CAPACITY AND FILTRATION PROPERTIES OF UPPER CRETACEOUS ROCKS (FROM THE DATA OF NORTH CAUCASUS BRANCH OF NIPINEFT)

\begin{tabular}{|c|c|c|c|}
\hline \multirow{2}{*}{ Deposits } & \multicolumn{2}{|c|}{ Hydrodynamic studies } & $\begin{array}{c}\text { Average } \\
\text { depth, m }\end{array}$ \\
\cline { 2 - 3 } & $\begin{array}{c}\text { Fracture } \\
\text { porosity, } \%\end{array}$ & $\begin{array}{c}\text { Permeability, } \\
\boldsymbol{m} \boldsymbol{D}\end{array}$ & \\
\hline Malgobek-Voznesenskoye & 0.35 & 245 & 2850 \\
\hline Khayan-Kortovskoye & 0.16 & 34 & 3500 \\
\hline Eldarovskoye & 0.28 & 500 & 4050 \\
\hline Bragunskoye & 0.29 & 476 & 4650 \\
\hline Goryacheistochnenskoye & 0.2 & 84 & 4300 \\
\hline Gudermesskoye & 0.16 & 70 & 5000 \\
\hline Mineralnenskoye & 0.06 & 17 & 5100 \\
\hline Zamankulskoye & 0.25 & 205 & 2200 \\
\hline Karabulak-Achalukskoye & 0.25 & 256 & 2200 \\
\hline Starogroznenskoye & 0.32 & 398 & 4600 \\
\hline
\end{tabular}

TABLE III. CAPACITY AND FILTRATION PROPERTIES OBTAINED BY FIELD GEOPHYSICAL TESTS (FROM THE DATA OF NORTH CAUCASUS BRANCH OF NIPINEFT)

\begin{tabular}{|c|c|c|c|c|}
\hline \multirow[b]{2}{*}{ Deposits } & \multicolumn{3}{|c|}{$\begin{array}{c}\text { Field geophysical } \\
\text { tests }\end{array}$} & \multirow[b]{2}{*}{ 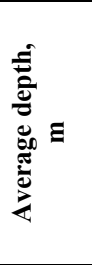 } \\
\hline & 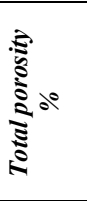 & 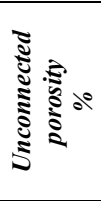 & 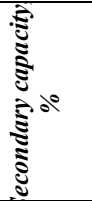 & \\
\hline $\begin{array}{c}\text { Malgobek- } \\
\text { Voznesenskoye }\end{array}$ & 5.4 & 4.6 & 0.8 & 2850 \\
\hline Khayan-Kortovskoye & 3.57 & 2.6 & 0.97 & 3500 \\
\hline Eldarovskoye & 3.06 & 2.54 & 0.52 & 4050 \\
\hline Bragunskoye & 2.83 & 2.25 & 0.58 & 4650 \\
\hline Goryacheistochnenskoye & 5.62 & 5.0 & 0.62 & 4300 \\
\hline Gudermesskoye & 1.47 & 0.97 & 0.5 & 5000 \\
\hline Mineralnenskoye & 1.38 & 1.0 & 0.38 & 5100 \\
\hline Zamankulskoye & 4.65 & 2.6 & 2.05 & 2200 \\
\hline $\begin{array}{c}\text { Karabulak- } \\
\text { Achalukskoye }\end{array}$ & 3.16 & 2.6 & 0.56 & 2200 \\
\hline Starogroznenskoye & 6.03 & 5.3 & 0.73 & 4600 \\
\hline
\end{tabular}

\section{CONCLUSION}

1. The results of the conducted research have not only theoretical, but also important practical value, mainly for targeting of exploratory works.

2. The proposed method for prediction of fractured (secondary) porosity) in anticlinal structures may be employed for search of deep reservoirs with secondary porosity in terrigenic massifs, which are not prospective for search of granular reservoirs.

3. Economic efficiency of the proposed method lays in reduction of expenses for exploration of oil and gas deposits in deep reservoirs with secondary porosity by means of proving the practicality of drilling on the anticlinal structures revealed by seismic surveying.

\section{References}

[1] M.A. Artomonov, S.M. Bogorodsky, Features of manifestations of local elevations and regional faults in Ustyurt and Mangyshlak plateaus on high altitude aerospace photographs, Annals of Higher Education Institutions, Geology and Exploration, no. 12, 1974.

[2] O. Uze et al., Analysis of dynamic flow, KAPPA. 2008.

[3] M.R. Bembel, Mechanism of formation of anticlinal fields of hydrocarbons, Scientific Journal: Natural and Technical Sciences, pp. 1684-2626, 2012.

[4] A.Yu. Baturin, Geological and process modeling of development of oil and oil-and-gas deposits, Moscow: VNIIOENG.

[5] Z.G.. Borisenko. New theory and practice of spacial distribution of oil and gas fields in fractured reservoirs, A monograph. Pyatigorsk: PGLU press, 2010

[6] A.A. Dubkov, Influence of pressure and temperature onto mechanical properties of oil and gas reservoir rocks, «NTV Well Logger», Tver: AIS, No. 12, pp. 73-82, 2008.

[7] I.A. Kerimov, M.Ya. Gaysumov, Powerful earthquakes in the territory of the Chechen Republic. Annals of the Academy of Sciences of the Chechen Republic, no.1 (12), pp. 57-62, 2010.

[8] Z.Kh. Mollayev, Predicting reservoirs in carbonate rocks of TerekCaspian depression. Author's abstract of a dissertation for the Candidate degree in Geology and Mineral Science, Moscow, 1985.

[9] A.V. Raspopov, A.A. Schipanov, Influence of dynamic deformation of fractured porous reservoir onto oil production, Oil Industry, No. 6, p. 97, 2002

[10] [10] B.L. Aleksandrov, I.A. Kerimov, M.A. Khasanov, A.S. Elzhayev, A method of predicting the areas of secondary fractured type reservoirs in the sedimentary sheath. Patent no. 2520067 issued 18.04.2014.

[11] B.V. Terentyev, V.V. Plontikov, A.A. Shipanov, Changes in capacity and filtration properties of carbonate collectors during the development of oil fields: influence onto modeling results, experimental modeling, Geology, Geophysics and Development of Oil and Gas Deposits, no. 5-6, pp. 5966, 2005.

[12] S.S. Cherepanov et al., «Determining the fracturing parameters of rocks on the basis of complex studies of core, hydrodynamic and geophysical surveys of wells, Oil Industry, No 2, pp. 94-96, 2014

[13] Blanchet P.H. Development of Fracture Analysis as Exploration Method, Bull. AAPG, 41, pp. 1748, 1957.

[14] S.S. Gatsaeva, B. L. Aleksandrov, M.A. Hasanov, B. L. A.S. Eljayev, T.B Ezirbaev, Forecasting cracked collectors on anticlinal type structures at late stage of exploration in oil and gas area, IOP Conf. Series: Earth and Environmental Science, 87, pp. 052008, 2017.

[15] I.A. Kerimov, E.A. Abubakarova, S.V. Badaev, «Tridimensional analysis of the gravitational and magnetic fields of the Terek-Caspian trough», IOP Conference Series: Earth and Environmental Science, 87, pp. 052011, 2017. 